\title{
Trans-Atlantic Propagation of 1755 Tsunami and Its Effects on the French West Indies
}

\author{
Narcisse Zahibo ${ }^{1}$, Efim Pelinovsky ${ }^{*}, 1,2,3$, Ahmet Yalciner ${ }^{4}$, Andrey Zaitsev ${ }^{5}$, Tatiana Talipova ${ }^{2}$, \\ Irina Nikolkina ${ }^{1,2}$, Anton Chernov ${ }^{2}$, Isil Insel ${ }^{4}$, Derya Itir Dilmen ${ }^{4}$ and Ceren Ozer ${ }^{4}$ \\ ${ }^{I}$ Physics Department, Université des Antilles et de la Guyane, Pointe-à-Pitre, Guadeloupe, France \\ ${ }^{2}$ Department of Nonlinear Geophysical Processes, Institute of Applied Physics, Nizhny Novgorod, Russia \\ ${ }^{3}$ National University -High School of Economics, Nizhny Novgorod, Russia \\ ${ }^{4}$ Ocean Engineering Research Center, Department of Civil Engineering, Middle East Technical University, Ankara, \\ Turkey \\ ${ }^{5}$ Special Research Bureau for Automation of Marine Researches, Uzhno-Sakhalinsk, Russia
}

\begin{abstract}
The present study examines the propagation of tsunami waves generated by the 1755 Lisbon earthquake in the Atlantic Ocean and its effects on the coasts of the French West Indies in the Caribbean Sea. Historical data of tsunami manifestation in the French West Indies are briefly reproduced. The mathematical model named NAMI DANCE which solves the shallow-water equations has been applied in the computations. Three possible seismic source alternatives are selected for 1755 event in the simulations. The results obtained from the simulations demonstrate that the directivity of tsunami energy is divided into two strong beams directed to the southern part of North America (Florida, the Bahamas) and to the northern part of South America (Brazil). The tsunami waves reach the Lesser Antilles in 7 hrs. The computed distribution of tsunami wave height along the coasts of Guadeloupe and Martinique are presented. Calculated maximum wave amplitudes reached $2 \mathrm{~m}$ in Guadeloupe and $1.5 \mathrm{~m}$ in Martinique. These results are also in agreement with observed data $(1.8-3 \mathrm{~m})$. The experience and data obtained in this study show that transatlantic events must also be considered in the tsunami hazard assessment and development of mitigation strategies for the French West Indies.
\end{abstract}

Keywords: Tsunami, 1755 Lisbon Earthquake, French West Indies, Caribbean Sea, Tsunami propagation, Atlantic Ocean, Tsunami simulation, Trans-oceanic.

\section{INTRODUCTION}

The strong earthquake occurred on November 1, 1755 near the Portuguese Coast and induced the catastrophic tsunami that affected many European countries in the coast of the Atlantic Ocean. Lisbon tsunami propagated through the Atlantic Ocean and reached the Lesser Antilles (Fig. 1). Data of tsunami manifestation in the Lesser Antilles are given in different catalogues and papers [1-10]. We reproduce here the description of the 1755 tsunami and its effects in the French West Indies. "The sea waves swept across the Atlantic and were observed in several of the West Indian Islands, where the usual rise of the tide is little more than 2 feet $[60 \mathrm{~cm}]$. In St. Martin, the sea retired so far that a sloop, riding at anchor in 15 feet [4.6 m] of water, was laid dry on her broadside. In Martinique and most of the French Islands, it overflowed the low land, and returned quickly to its former boundaries. In the West Indies, this extraordinary motion of the waters was observed 6 hours after the first shock was felt at Lisbon. In Martinique, in that remarkable flux and reflux of the sea, some places were left dry on about a mile [1.5 km]". Near Fort-de-France,

*Address correspondence to this author at Institute of Applied Physics, Nizhny Novgorod, Russia; Tel: +78314164839; Fax: +78314365976;

E-mail: pelinovsky@hydro.appl.scinnov.ru
Martinique "sea withdrew $1.6 \mathrm{~km}$ and returned to inundate the upper floors of houses" [11]. Recently, Morton et al., [12] found the probable geological evidence of the 1755 tsunami on the east coast of Grande-Terre (Guadeloupe) at Anse Ste-Marguerite and Anse Maurice on a height of 2-3 m (Fig. 1).

Tsunami propagation through the Atlantic Ocean to the French West Indies is studied in the present paper. The data of the earthquake parameters and tsunami source are discussed in the section 2 . We use three possible sources of the 1755 earthquake. The numerical model applied to compute tsunami propagation through the Atlantic is based on the shallow-water theory (section 3 ). Tsunami characteristics and the directivity of the tsunami energy in Atlantic Ocean are discussed in section 4. Results of numerical simulations and computed tsunami characteristics for the coasts of Guadeloupe and Martinique are presented in sections 5 and 6. The results are summarized and discussed in the Conclusion.

\section{EARTHQUAKES AND TSUNAMI SOURCE}

The rupture parameters of the 1755 Lisbon Earthquake were not well defined even though the coordinates of the earthquake epicenter are known approximately. For instance, 


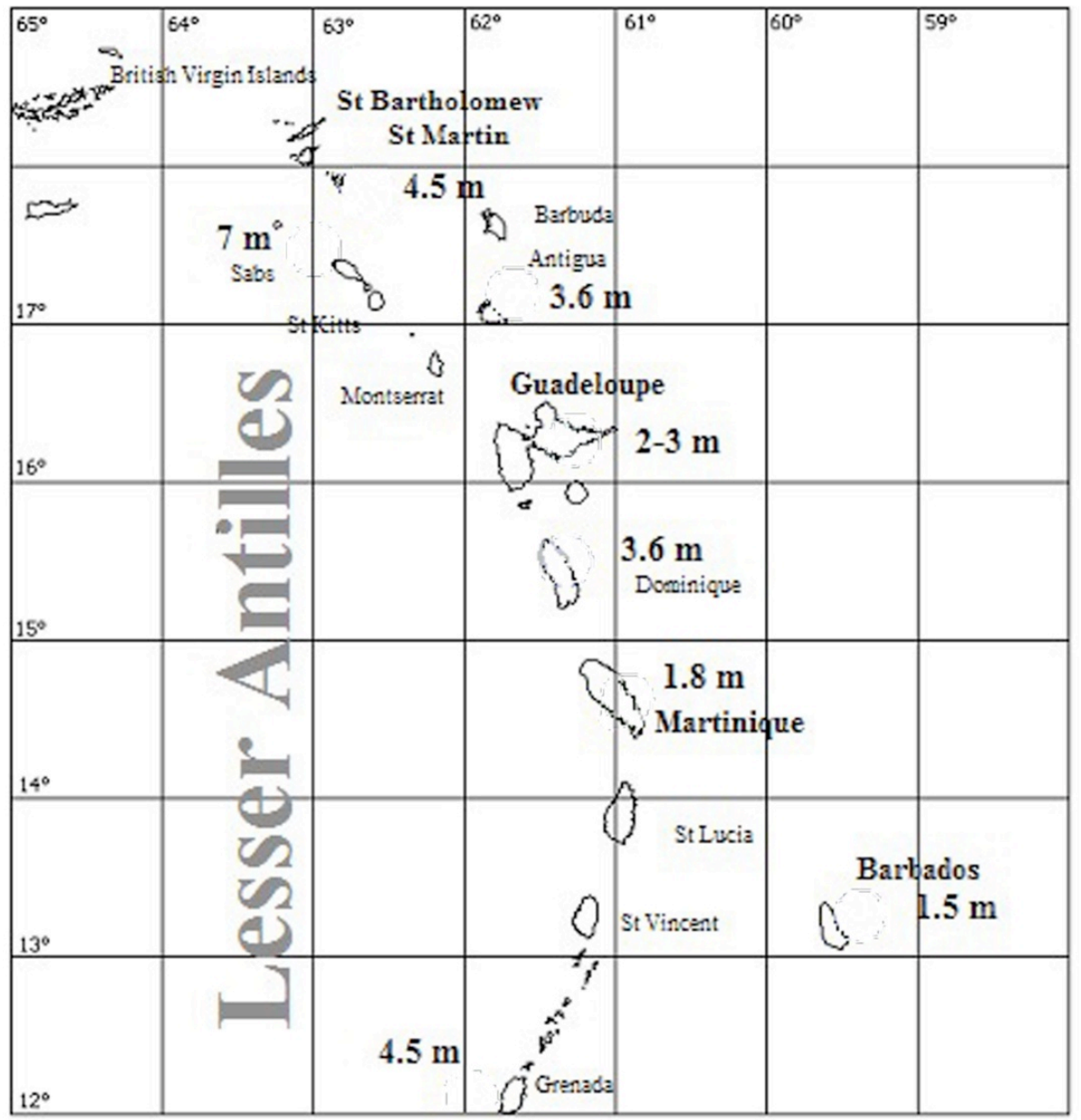

Fig. (1). The 1755 tsunami records in the Lesser Antilles.

Johnston [13] assumed that the earthquake occurred in the Gorringe Bank as marked in between symbols ?? in Fig. (2) [14]. The other location of the 1755 rupture named Marquis de Pombal (marked as Mq. Pomb. in Fig. (2)) is analyzed in $[15,16]$. Two other candidates for the earthquake epicenter are the Horseshoe Fault (HF) and Gudalquivir Bank (GB). The well-documented 1969 [17] event occurred at HF [18, 19] and GB located near the Gibraltar [9].

Taking into account that the 1755 event occurred in the same area that the 1969 tsunami, many parameters of the 1755 earthquake are considered to be the same as those of the 1969 event. Meanwhile, the magnitude of the 1755 earthquake $\left(\mathrm{M}_{\mathrm{L}}=8.5\right)$ is estimated to be bigger than magnitude of the 1969 event $(\mathrm{Mw}=7.9)$. According to Gjevik et al. [20] parameters of the 1969 earthquake lead to the positive water displacement of $3.5 \mathrm{~m}$ and the negative depression of $2.4 \mathrm{~m}$ according to the tsunami source computation by Okada [21]. For the 1755 event the fault area should be enlarged. Baptista et al. [9] suggested the composite source of the 1755 tsunami source, located on Marquis de Pombal and Guadalquivir Bank. The fault parameters of two composite segments are the following, Marquis de Pombal Tsunami fault (MPTF): $105 \mathrm{~km}$ long, 55 $\mathrm{km}$ wide, dip angle $24^{\circ}$, strike $21.7^{\circ}$, slip $20 \mathrm{~m}$; GB: $96 \mathrm{~km}$ long, $55 \mathrm{~km}$ wide, dip $45^{\circ}$, strike $70^{\circ}$, slip $20 \mathrm{~m}$. The estimation of rupture parameters of 1755 historical source has been recently done by Stich et al. [22], where the fault
(HF) is proposed to be $315 \mathrm{~km}$ long and $60 \mathrm{~km}$ wide, with dip angle of $55^{\circ}$. In the recent paper [23] the impact of the 1755 tsunami on the UK coast is analyzed, the best results are achieved if the tsunami source is located on the north of Gorringe Bank. Also we would like to point out the paper by Mader [24] where tsunami source $(300 \mathrm{~km}$ in radius and height $30 \mathrm{~m}$ ) is located near the Azores-Gibraltar fracture zone and the Gorringe Bank. Recently teletsunami effect on the Lesser Antilles has been studied by [25] and the source of two strongly different orientations (practically perpendicular one to another) has been taken based on source of [26]. Nevertheless the computed tsunami wave heights differed only up to $30 \%$.

The careful macroseismic analysis was performed by Gutscher et al. [14] who reconstructed source parameters of the 1755 event, and compared it with source characteristics of strong earthquakes in the region (1969 and 1964). The source is positioned in front of Gibraltar (Fig. 2) and is proposed as three subduction planes. Considering that the magnitude of the 1755 earthquake is $\mathrm{M}_{\mathrm{L}}=8.5$, Gutscher et al. [14] suggested to increase the slip dislocation up to 20 $\mathrm{m}$, and to augment the fault length and fault width up to 180 $\mathrm{km}$ in direction NS and $210 \mathrm{~km}$ in direction EW, correspondingly. We chose the earthquake source located between the Gorrige bank and the Gibraltar subduction, with rupture parameters close to suggested by Gutscher et al. [14]: fault length is $180 \mathrm{~km}$, fault width is $210 \mathrm{~km}$. The focal depth is 


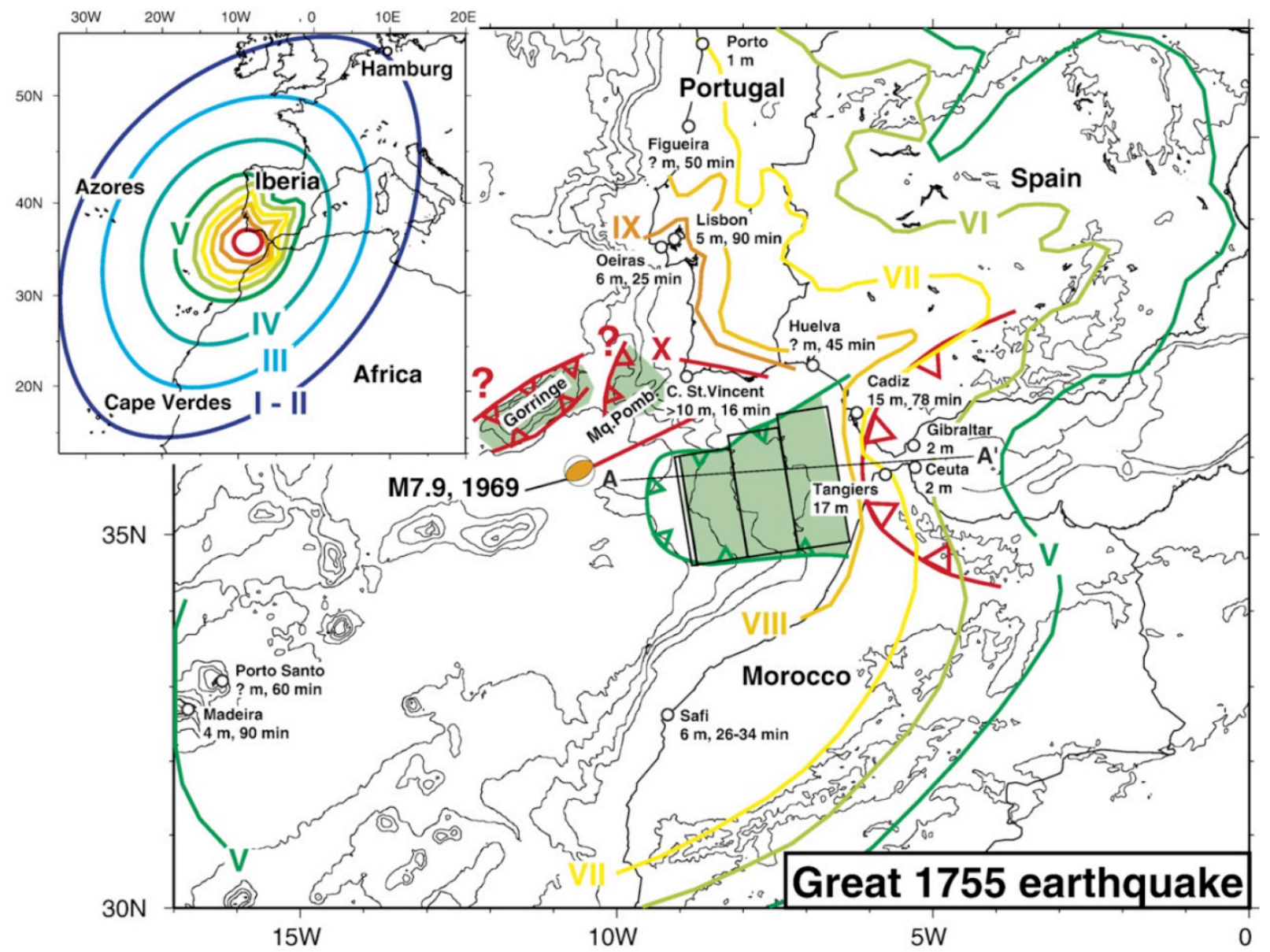

Fig. (2). Isoseismal map of the 1755 earthquake [14].

chosen on $22 \mathrm{~km}$, the dip angle is $15^{\circ}$ and rake angle is $100^{\circ}$. The slip dislocation of $19 \mathrm{~m}$ is increased in comparison with the 1969 event as it was recommended in [14]. The strike angle is $55^{\circ}$. Our goal is to study long distance tsunami propagation in Atlantic Ocean. Usually for tsunami on long distances fine structure of tsunami source is not important as dimensions and orientation, see also paper by Roger et al. [25] for another earthquake source. Here we would like to analyze effect of influence of orientation of "Gutscher" source on tsunami characteristics and chose several values of strike angle $\left(55^{\circ}, 80^{\circ}\right.$, and $\left.105^{\circ}\right)$.

Table 1. Rupture Parameters for 3 Different Source Alternatives

\begin{tabular}{|c|c|}
\hline Source & I/II/III \\
\hline \hline Focal Depth $(\mathrm{km})$ & 22 \\
\hline Fault Length (km) & 180 \\
\hline Fault Width (km) & 210 \\
\hline Slip Dislocation (m) & 19 \\
\hline Dip Angle (deg) & 15 \\
\hline Rake Angle (deg) & 100 \\
\hline Strike Angle (deg. CW) & 8.14 \\
\hline Maximum Positive Amplitude (m) & \\
\hline
\end{tabular}

The selected rupture parameters of the source alternatives (I, II, III) are summarized in the Table 1. The tsunami sources are computed according to [21] for these source alternatives are also given in Fig. (3). Initial wave amplitudes (both positive and negative) are almost the same for all source alternatives: the water elevation in the source is 8.14 $\mathrm{m}$, and the depression is $2.66 \mathrm{~m}$ (Table $\mathbf{1}$ ).

\section{NUMERICAL MODEL}

To describe the transoceanic propagation of the 1755 event in the Atlantic from its source to the Caribbean, it is appropriate to use the shallow-water theory in numerical simulations. The governing equations in spherical coordinates on the rotated earth are given below:

$$
\frac{\partial M}{\partial t}+\frac{1}{R \cos \theta} \frac{\partial}{\partial \lambda}\left(\frac{M^{2}}{D}\right)+\frac{1}{R \cos \theta} \frac{\partial}{\partial \theta}\left(\frac{M N \cos \theta}{D}\right)+\frac{g D}{R \cos \theta} \frac{\partial \eta}{\partial \lambda}=f N
$$

$\frac{\partial N}{\partial t}+\frac{1}{R \cos \theta} \frac{\partial}{\partial \lambda}\left(\frac{M N}{D}\right)+\frac{1}{R \cos \theta} \frac{\partial}{\partial \theta}\left(\frac{N^{2} \cos \theta}{D}\right)+\frac{g D}{R} \frac{\partial \eta}{\partial \theta}=-f M$

$\frac{\partial \eta}{\partial t}+\frac{1}{R \cos \theta}\left[\frac{\partial M}{\partial \lambda}+\frac{\partial}{\partial \theta}(N \cos \theta)\right]=0$ 

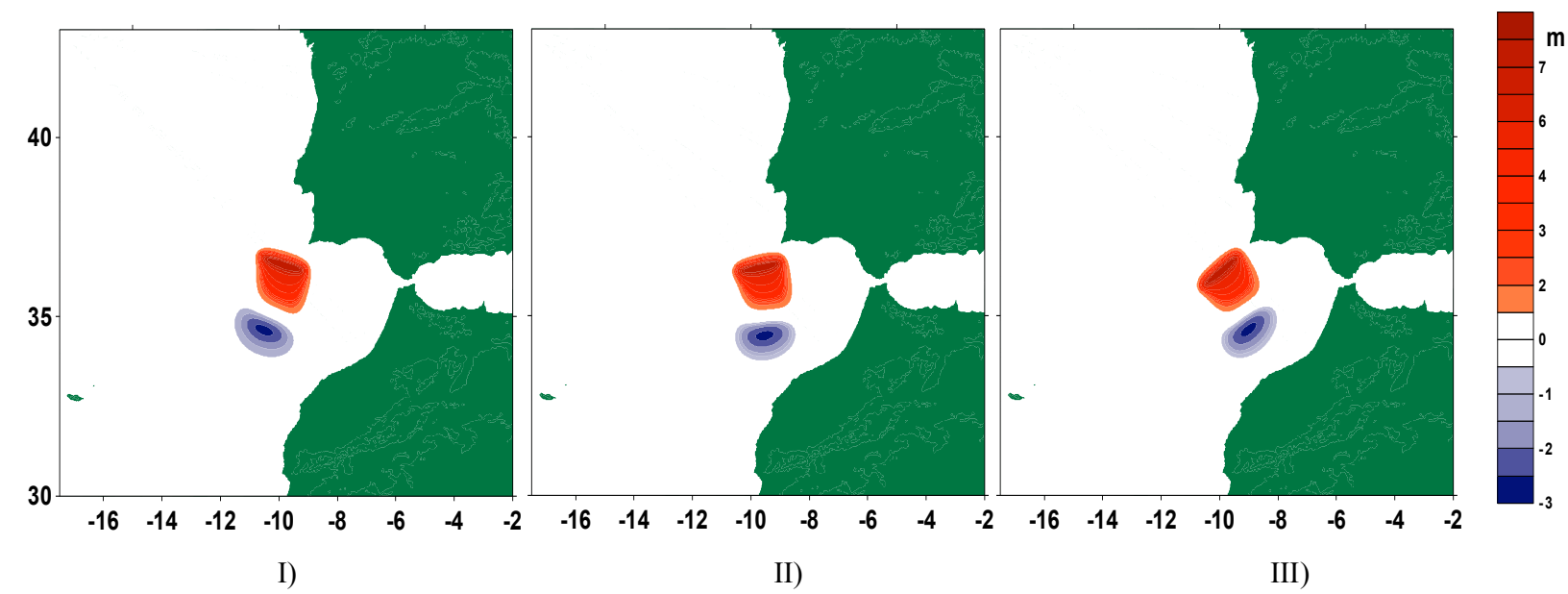

Fig. (3). Computed tsunami sources for three different source alternatives.

where $\eta$ is the water surface displacement, $M$ and $N$ are components of water discharge fluxes along latitude $\theta$ and longitude $\lambda$ directions, $D=h(x, y)+\eta$ is the total water depth, $h(x, y)$ is the unperturbed depth, $g$ is acceleration due to gravity, $t$ is time, $R$ is the Earth's radius, $f$ is the Coriolis parameter $(f=2 \omega \sin \theta), \omega$ is the Earth rotation frequency.

The propagation of the 1755 event is simulated by using the computational tool NAMI DANCE, which is particularly developed for tsunami simulations and visualizations. The code applies the nonlinear form of shallow-water equations (Eqs. 1-3) using a leapfrog scheme in finite difference technique for basins of irregular shape, bathymetry and topography [27, see also http://namidance.ce.metu.edu.tr] and is based on TUNAMI N2 software package [28]. NAMI DANCE was tested, validated and verified together with other internationally accredited tsunami computational tools (such as MOST, TUNAMI N2, COMCOT) in the Project acronymed TRANSFER (Tsunami Risk And Strategies for European Region) funded by the European Commission. NAMI DANCE previously was used for the modeling of the 2004 Indian Ocean Tsunami [29], several historic and prognostic events in the Caribbean [5,6], in the Mediterranean [30], in the Sea of Marmara [31], and in the Black Sea [32].

The boundaries of the study domain in numerical simulations are selected between $\left(8^{\circ} \mathrm{N}\right.$ to $\left.43^{\circ} \mathrm{N}\right)$ and $\left(82^{\circ} \mathrm{W}\right.$ to $2^{\circ}$ ), which include Portugal and the French West Indies. As for the bathymetric database, the 1-minute resolution bathymetry of the study domain is extracted from the GEBCO database (GEBCO Digital Atlas, British Oceanographic Data Centre). In our numerical computations, the fully reflected boundary conditions (vertical wall approximations) in the last "sea" grid points (at the depth around 10$20 \mathrm{~m}$ ) are applied. However, the runup and inundation are disregarded. On the open north and south oceanic boundaries the condition of free wave passage is applied.

\section{COMPUTED TSUNAMI CHARACTERISTICS IN THE ATLANTIC OCEAN}

In the simulations three different source alternatives have been used as separate inputs. The arrival time of tsunami wave at a specified location is determined when the water elevation exceeds $15 \mathrm{~cm}$ (uplift or subsidence) at this location. The travel time map showing the location of the wave front at 60 minutes intervals is given in Fig. (4) for the simulation of source alternative I. There is no significant difference is detected when the travel time curves of three source alternatives are compared. Simulation results indicated that the tsunami waves approached the French West Indies (particularly, Guadeloupe and Martinique) in 7 hours $(430 \mathrm{~min})$. This result is in agreement with [20, 24, 33].

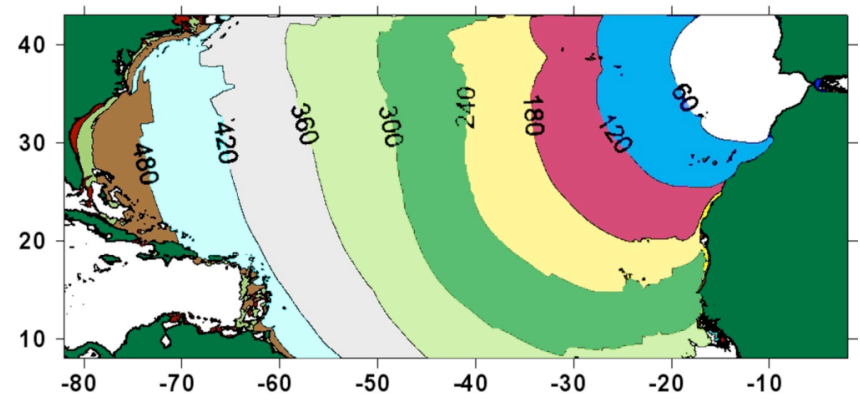

Fig. (4). Tsunami travel time curvey in minutes (Source Alternative I).

The spatial distributions of positive (red tones, in the top of pictures) and negative (blue tones, in the bottom of pictures) maximal amplitudes of tsunami wave are presented in Fig. (5) for three source alternatives. The ray propagation is clearly observed, especially for negative amplitudes. According to the simulation results, two main beams of wave energy propagation appear for these selected source alternatives. One beam is directed to the area of Florida and the Bahamas; the second one reaches the Brazilian coast.

The beam in the first alternative (where the strike angle is selected as $105^{\circ}$ ) is directed to Brazil and divided into two paths with maximum positive wave amplitudes $(10 \mathrm{~cm}$ in the open ocean), which is less than near the Florida and Bahamas $(20 \mathrm{~cm}$ in the open ocean, and up to $1 \mathrm{~m}$ near the Bahamas) (Fig. 5-I). Moreover, only one beam with negative amplitude ended in Brazilian coast is visible $(-20 \mathrm{~cm}$ in the ocean), and amplitudes are comparable with those in Florida and the Bahamas $(-20 \mathrm{~cm}$ in the open ocean). It is particularly remarkable that both positive amplitude paths 


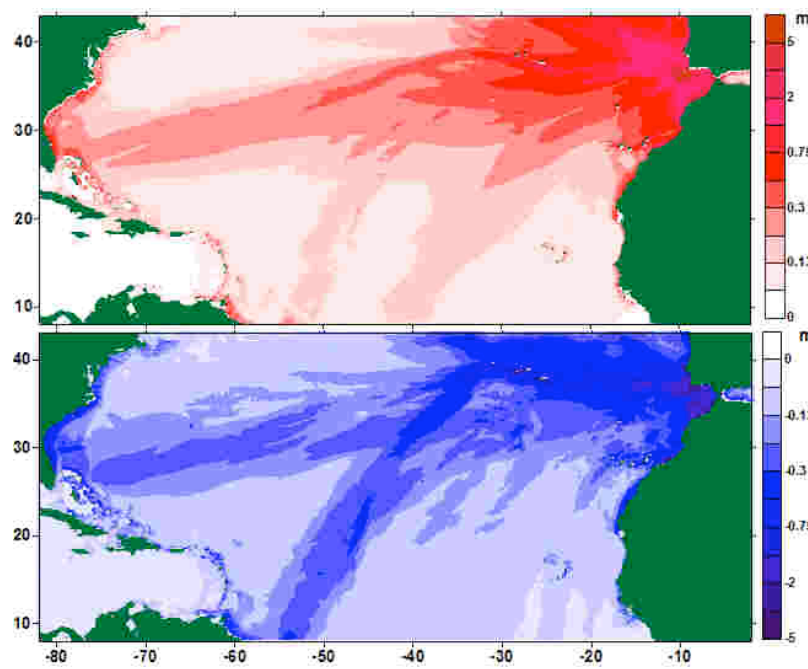

I)

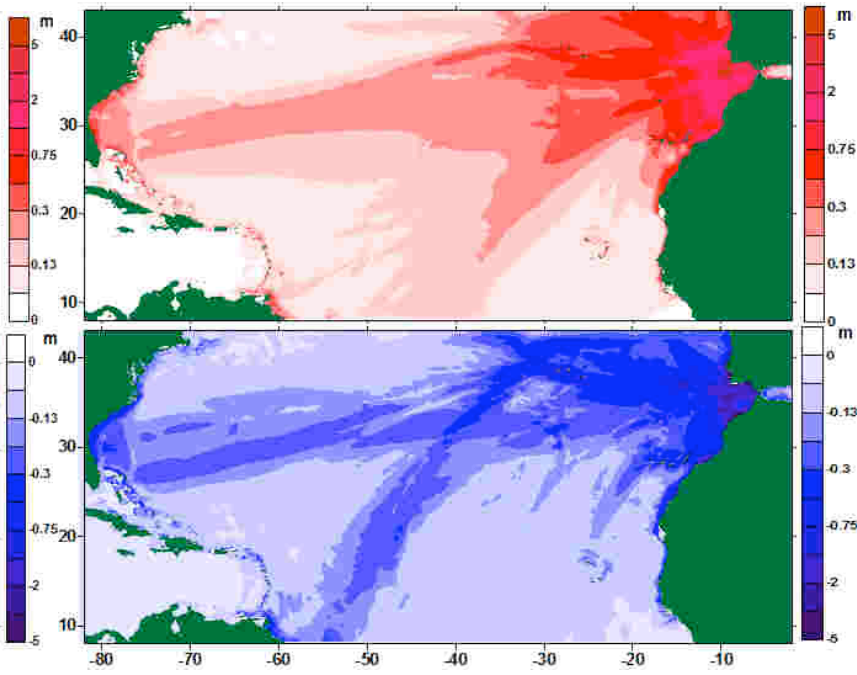

II)

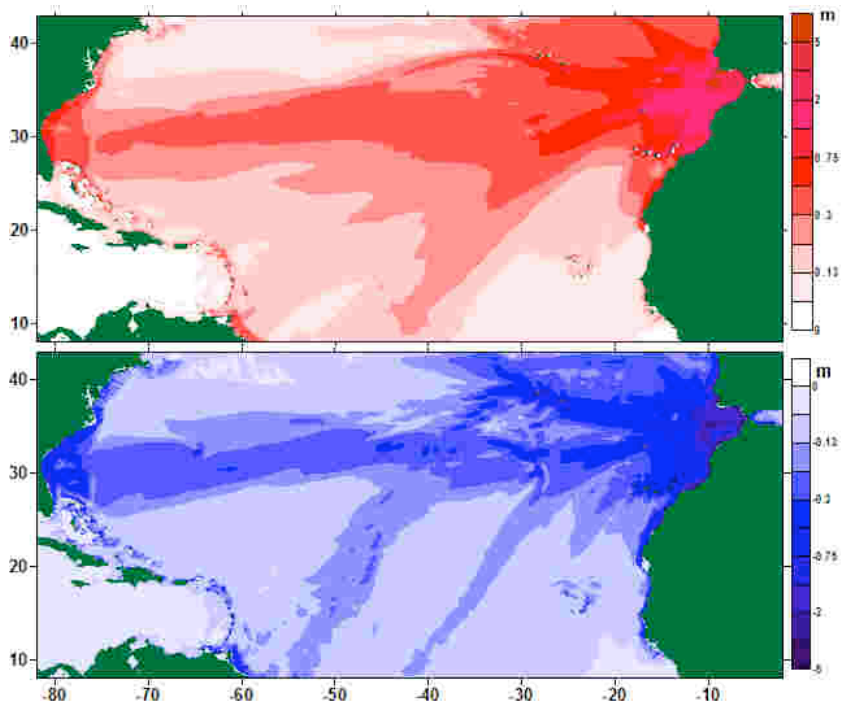

III)

Fig. (5). Distribution of maximum positive (pink, above) and negative (blue, below) amplitudes of tsunami waves in Atlantics.

(one reaches to north border of the map between $38^{\circ} \mathrm{W}$ $42^{\circ} \mathrm{W}$; and another reaches south border of the map between $50^{\circ} \mathrm{W} 55^{\circ}$ ) have the similar location as the paths of negative amplitudes.

The spatial distribution of maximum amplitude of the wave computed by using source alternative II, (where the strike angle is $80^{\circ}$ ) is given in Fig. (5-II). Two positive amplitude paths oriented to Brazil are merged, and the resulting path is oriented to the Brazilian coast (it reaches to south border of the map between $40^{\circ} \mathrm{W} 50^{\circ} \mathrm{W}$ ). According to the simulation results, the path of maximum negative amplitudes reaches the Brazilian coast (between $50^{\circ} \mathrm{W}$ and $60^{\circ} \mathrm{W}$ ). Maximum positive amplitudes are obtained as $20 \mathrm{~cm}$ for Florida, and $10 \mathrm{~cm}$ for Brazil. The negative amplitudes are computed as $-20 \mathrm{~cm}$ in the open ocean.

For the third source alternative (where the strike angle is $55^{\circ}$ ), the directivity of tsunami energy seems similar to the others. Two beams for both amplitude polarities oriented on Brazil and Florida are clear (Fig. 5-III) as others. The maximum positive amplitudes that appeared in the open ocean are somewhat larger than those obtained in the previous source alternatives. They are $30 \mathrm{~cm}$ near Florida and the Bahamas; and 10 to $20 \mathrm{~cm}$ near Brazil. The maximum negative amplitudes in the open ocean in the Florida path are $-20 \mathrm{~cm}$, and in the Brazilian path are about $-10 \mathrm{~cm}$. According to the simulation results, the tsunami amplitudes near Florida and Brasil are greater in source alternative III, comparing to other alternatives.

The main conclusion from the simulations is that in the case of tsunami generated in the vicinity of the Portuguese coast, the tsunami energy is directed towards Brazilian and Florida coast and the region near Lesser Antiles remains less affected. Similar results have recently been obtained by Lovholt [33], who studied tsunami source located near the Canary Islands, and his results demonstrate similar characteristics of tsunami propagation in the Atlantics.

The snapshots of the wave field 7 hours after the earthquake are shown in Fig. (6) for different source alternatives. The wave field is irregular due to the effects of reflection, refraction and diffraction. The main structures of the wave 


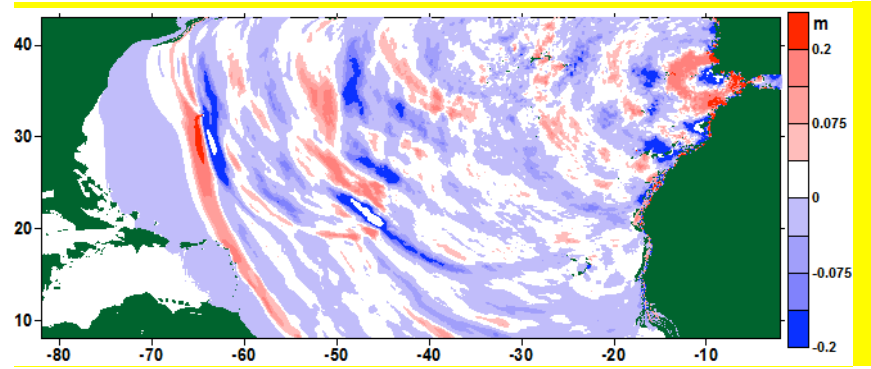

I)

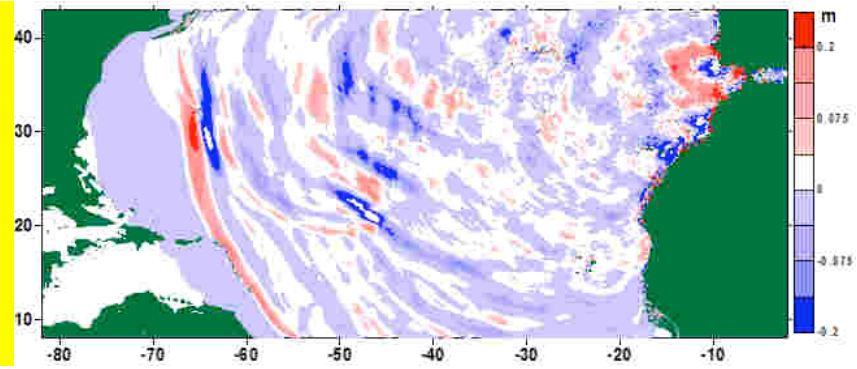

II)

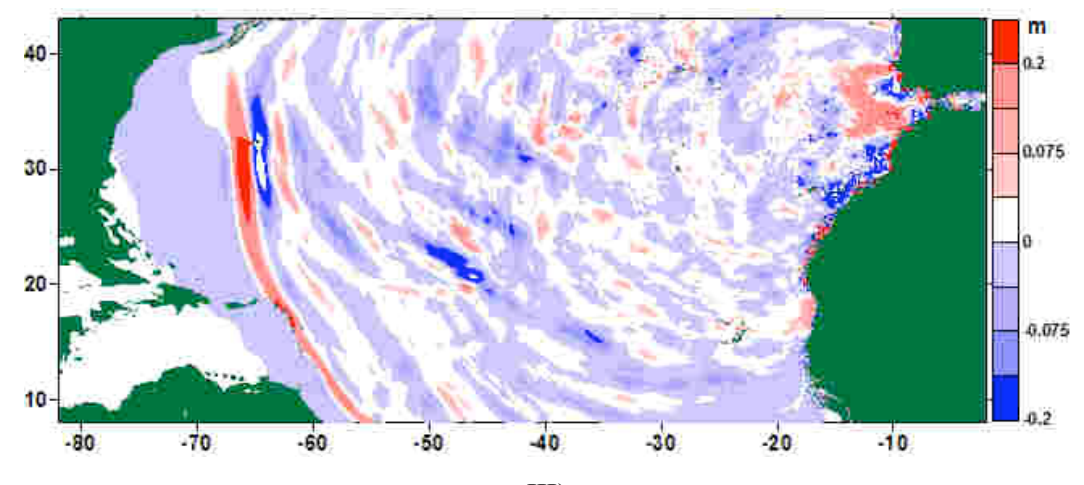

III)

Fig. (6). Snapshots of tsunami 7 hours after the earthquake (for different source alternatives I, II, III).

field are rather similar for all sources, but the variability of wave amplitudes and fine structure elements are clearly observed.

\section{COMPUTED CHARACTERISTICS OF TSUNAMI IN THE COASTAL ZONE OF GUADELOUPE}

In order to understand the wave characteristics in the vicinity of Guadeloupe, we located a virtual tide gauge in the northern coast of Guadeloupe $\left(16.39^{\circ} \mathrm{N}, 61.60^{\circ} \mathrm{W}\right)$ between Basse-Terre and Grand-Terre (Fig. 7). The excess amplification of the wave is observed in this area since the water depth is shallower than other coastal regions in Guadeloupe.

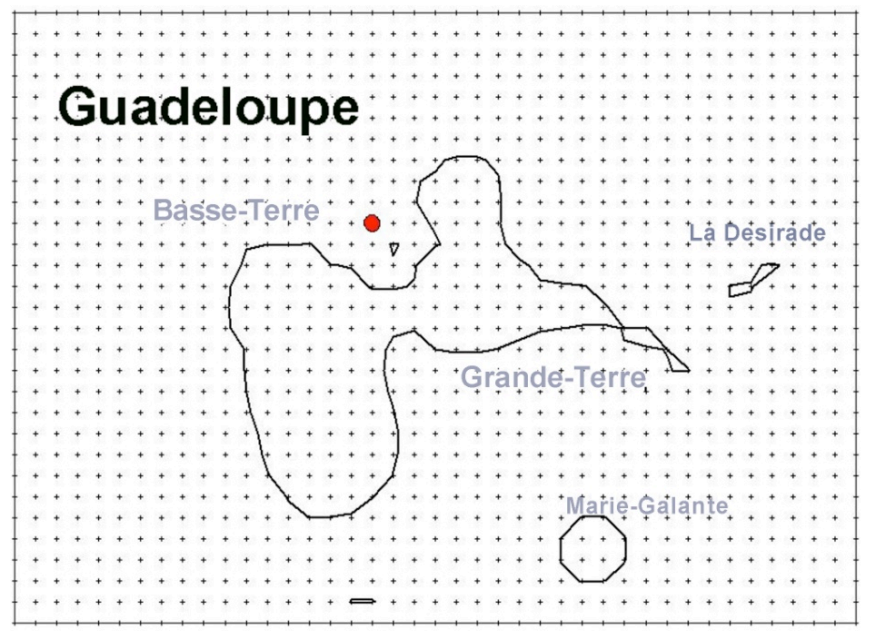

Fig. (7). Location of virtual tide gauge (red point) in the northern Guadeloupe where the time series of water surface fluctuations are computed.
Computed time series of tsunami at the virtual tide gauge are presented in Fig. (8) for the three source alternatives. In general, the different time series related to three different sources are similar. There is no (Source I) or negligible (5 $\mathrm{cm}$ or less; Source II and III) leading depression wave in front of the tsunami is computed. In all cases, the amplitude of second crest wave was found higher than the first. The characteristics of the leading wave (depression or elevation) depend directly on the orientation (strike angle) of the rupture when the other rupture parameters are same. In our applications the difference in strike angle in each source alternative resulted with minor differences in the time histories.

The positive amplitudes of the first waves vary from 26 $\mathrm{cm}$ (source I) to $44 \mathrm{~cm}$ (source III). The negative amplitudes of the first waves vary from $-33 \mathrm{~cm}$ (source II) to $-40 \mathrm{~cm}$ (sources I, III). The peak amplitudes of the second waves are in between $0.38 \mathrm{~cm}$ (source I) and $57 \mathrm{~cm}$ (source III). The lowest trough reaches $-66 \mathrm{~cm}$ (source I) with the second wave among all alternatives.

Characteristic period of the first and second waves (according to zero up crossing method) are obtained as 40 and 45 minutes respectively for all source alternatives.

Our computations demonstrate that the wave amplitudes at north of Guadeloupe between Basse- Terre and Grand Terre are about $40-50 \mathrm{~cm}$ (wave heights are approximately 1 $\mathrm{m})$. Usually, the average amplification factor between the nearshore value and the runup value for the tsunami like long waves is 2-3 [34, 35]. According to our computations and the average amplification factor, we can estimate that, the tsunami runup height can reach $1-1.5 \mathrm{~m}$ in the northern coast of Guadeloupe between Basse Terre and Grand Terre. 


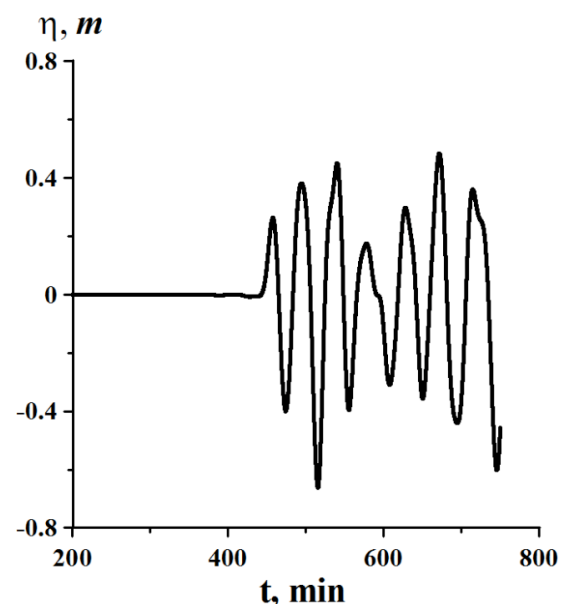

I)

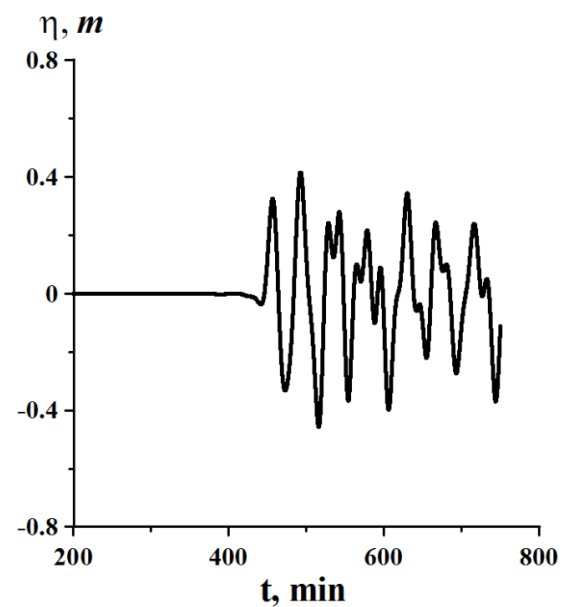

II)

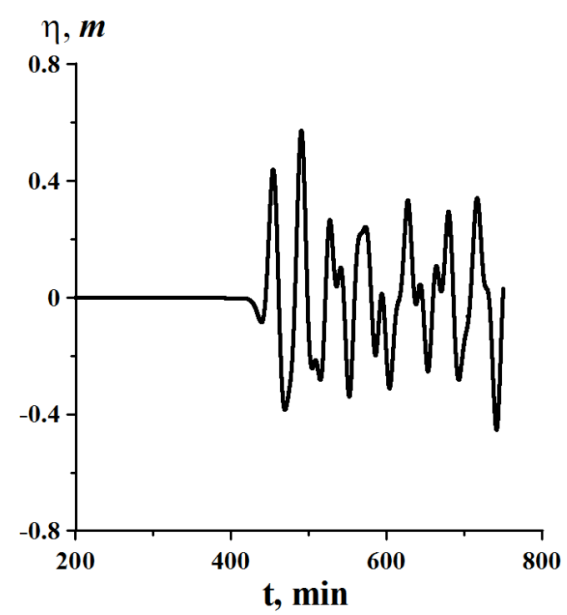

III)

Fig. (8). Computed time histories of water surface fluctuations at the point $\left(-61.60^{\circ} \mathrm{W}, 16.39^{\circ} \mathrm{N}\right)$ near Guadeloupe for different sources alternatives.

The computed maximum positive tsunami amplitudes at the different virtual tide gauge locations along the coast of Guadeloupe are given in Table 2, and presented in Fig. (9) as histogram. The locations of coastal settlements in Guadeloupe are shown in Fig. (10). It is evident that around the Guadeloupe the difference in tsunami wave height amplitudes generated by three sources consists of $15-20 \%$ and at few points this value grows to $30-35 \%$.

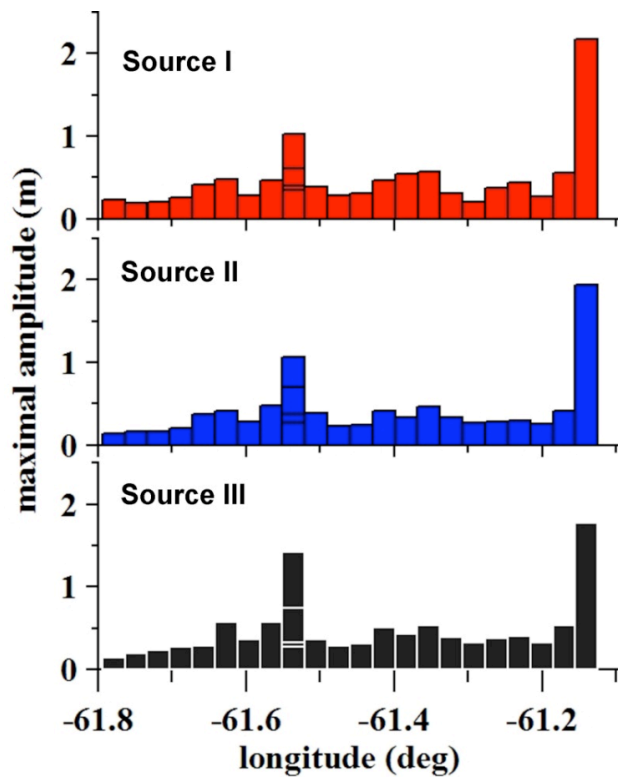

Fig. (9). Distribution of positive tsunami amplitudes along northern and north-eastern coasts of Guadeloupe.

According to the simulation results, there are only two locations (Point des Chateaux and Petit-Canal), where the computed tsunami amplitudes exceed $1 \mathrm{~m}$. At the virtual tide-gauge located near Point des Chateaux, east of Guadeloupe $\left(61.1397^{\circ} \mathrm{W} 16.2121^{\circ} \mathrm{N}\right)$, the tsunami amplitude are computed to be $2.17 \mathrm{~m}$ (source I), $1.94 \mathrm{~m}$ (source II), and $1.78 \mathrm{~m}$ (source III). Similarly, at the virtual tide-gauge located near Petit-Canal $\left(61.5356^{\circ} \mathrm{W} 16.3939^{\circ} \mathrm{N}\right)$, tsunami amplitudes are computed to be $1.03 \mathrm{~m}$ (source I), $1.07 \mathrm{~m}$ (source II), and $1.42 \mathrm{~m}$ (source III).
Although tsunami amplitudes are relatively modest, the southern part of Grande-Terre Island can be considered as the area of significant waves (a little less than $1 \mathrm{~m}$ ). It is interesting to note that on east Basse-Terre, near Petit-Bourg (Pointe à Bacchus) the tsunami amplitude is estimated as 72$95 \mathrm{~cm}$ also. All of sources give similar positive wave amplitude distributions (Fig. 9) with maxima except the above mentioned two locations.

Actually, there are no historical records available in Guadeloupe for 1755 tsunami, but our preliminary estimations considering the amplification factor correlate with observed heights of tsunami waves in Antigua and Dominica (3.6 $\mathrm{m})$, and data of geological evidence in Guadeloupe (2-3 $\mathrm{m})$ given in Morton et al., [12].

\section{COMPUTED CHARACTERISTICS OF TSUNAMI IN THE COASTAL ZONE OF MARTINIQUE}

In order to understand the wave characteristics in the vicinity of Martinique, the same analysis as for Guadeloupe is followed. The virtual tide gauge locations and the computed positive tsunami amplitudes are given in Table 3 . The difference in tsunami wave height amplitudes generated by three sources around Martinique consists of $20-30 \%$ in average.

The histograms showing the maximum tsunami amplitudes according to different source alternatives are also shown in Fig. (11). As seen from Fig. (11), the distributions of tsunami amplitudes are similar at east coast of Martinique when the results of the three source alternatives are compared. Out of 32, in 6 virtual tide gauge locations, the positive tsunami amplitude exceeds $1 \mathrm{~m}$ according to at least one of the three source alternatives (Fig. 11 and 12). The maximum positive tsunami amplitude is computed as $1.5 \mathrm{~m}$ (source I) in Bain du Simon $\left(60.8352^{\circ} \mathrm{W}, 14.6061^{\circ} \mathrm{N}\right)$. Almost the same amplitude $(1.4 \mathrm{~m})$ is computed near Sainte Marie $\left(60.9874^{\circ} \mathrm{W}, 14.7879^{\circ} \mathrm{N}\right)$. The tsunami amplitudes in Pointe de la Batterie $\left(60.8656^{\circ} \mathrm{W}, 14.7576^{\circ} \mathrm{N}\right)$ and SainteAnne $\left(60.9256^{\circ} \mathrm{W}, 14.4242^{\circ} \mathrm{N}\right)$ are about $1.14 \mathrm{~m}$ and $1.12 \mathrm{~m}$ respectively. In the remaining two locations, La Trinité 
Table 2. Computed Values of Maximum Tsunami Amplitude at Several Virtual Tide Gauge Locations Near the Coast of Guadeloupe

\begin{tabular}{|c|c|c|c|c|c|c|}
\hline & \multirow{2}{*}{ Neighbor village } & \multicolumn{2}{|c|}{ Tide-gauge location } & \multicolumn{3}{|c|}{ Maximum positive amplitude (m) } \\
\hline & & Longitude, ${ }^{\circ} \mathbf{W}$ & Latitude, ${ }^{\circ} \mathbf{N}$ & Source I & Source II & Source III \\
\hline 1 & Sainte-Rose & -61.6574 & 16.3636 & 0.41 & 0.38 & 0.29 \\
\hline 2 & Sainte-Rose & -61.6269 & 16.3636 & 0.48 & 0.41 & 0.57 \\
\hline 3 & Petit-Canal & -61.5660 & 16.3939 & 0.46 & 0.48 & 0.57 \\
\hline 6 & Port-Louis & -61.5356 & 16.4545 & 0.4 & 0.38 & 0.33 \\
\hline 7 & Anse-Bertrand & -61.5051 & 16.4848 & 0.39 & 0.39 & 0.37 \\
\hline 8 & Pointe du Lagon & -61.4138 & 16.4848 & 0.47 & 0.42 & 0.51 \\
\hline 9 & Pointe Archange Neau & -61.3833 & 16.3636 & 0.55 & 0.34 & 0.43 \\
\hline 12 & Anse à la Gourde & -61.1702 & 16.2424 & 0.56 & 0.42 & 0.54 \\
\hline 13 & Pointe des Châteaux & -61.1397 & 16.2121 & 2,17 & 1,94 & 1,78 \\
\hline 14 & Pointe la Chaise & -61.1702 & 16.1818 & 0.70 & 0.67 & 0.69 \\
\hline 15 & Petite Anse Kahouanne & -61.2311 & 16.2121 & 0.93 & 0.6 & 0.74 \\
\hline 16 & Anse Kahouanne & -61.2615 & 16.2424 & 0.93 & 0.65 & 0.84 \\
\hline 17 & Anse du Mancenillier & -61.2920 & 16.2424 & 0.68 & 0.53 & 0.85 \\
\hline 18 & Saint-François & -61.3224 & 16.2121 & 0.40 & 0.32 & 0.28 \\
\hline 19 & Pointe-à-Pitre & -61.5356 & 16.2121 & 0.59 & 0.44 & 0.38 \\
\hline
\end{tabular}

Table 3. Distribution of Maximum Wave Amplitude along the Eastern Coast of Martinique

\begin{tabular}{|c|c|c|c|c|c|c|}
\hline & Neighbor village & \multicolumn{2}{|c|}{ Tide-gauge location } & \multicolumn{3}{|c|}{ Maximum positive amplitude (m) } \\
\hline 1 & Pointe Laroche & 61.0483 & 14.8485 & 0.45 & 0.39 & 0.46 \\
\hline 2 & Le Lorrain & 61.0179 & 14.8485 & 0.39 & 0.35 & 0.5 \\
\hline 3 & Le Marigot & 61.0179 & 14.8182 & 0.68 & 0.67 & 0.87 \\
\hline 6 & La Trinité & 60.9570 & 14.7879 & 1.09 & 0.91 & 1,10 \\
\hline 7 & Tartane & 60.9265 & 14.7879 & 0.77 & 0.71 & 1,02 \\
\hline 8 & Anse L'Etang & 60.8961 & 14.7879 & 0.5 & 0.47 & 0.65 \\
\hline 9 & Château Dubuc & 60.8656 & 14.7879 & 0.48 & 0.3 & 0.43 \\
\hline 12 & Ile Ranville & 60.8352 & 14.6970 & 1.12 & 0.69 & 0.68 \\
\hline
\end{tabular}


(Table 3)Contd.....

\begin{tabular}{|c|c|c|c|c|c|c|}
\hline & \multirow{2}{*}{ Neighbor village } & \multicolumn{2}{|c|}{ Tide-gauge location } & \multicolumn{3}{|c|}{ Maximum positive amplitude (m) } \\
\hline & & Latitude, ${ }^{\circ} \mathbf{W}$ & Longitude, ${ }^{\circ} \mathbf{N}$ & Source 1 & Source 2 & Source 3 \\
\hline 13 & Pointe Rouge & 60.8656 & 14.6970 & 0.84 & 0.86 & 0.76 \\
\hline 14 & Pointe Larose & 60.8656 & 14.6667 & 0.82 & 0.72 & 0.45 \\
\hline 15 & Pointe Boyce & 60.8352 & 14.6667 & 0.95 & 0.63 & 0.67 \\
\hline 16 & Fonds blancs & 60.8656 & 14.6363 & 0.88 & 0.64 & 0.73 \\
\hline 17 & Pointe Camphre & 60.8352 & 14,6363 & 0,54 & 0,53 & 0.93 \\
\hline 18 & Bain du Simon & 60.8352 & 14.6061 & 1.48 & 1.04 & 0.90 \\
\hline 19 & Le Vauclin & 60.8047 & 14.5758 & 0.99 & 0.88 & 1,06 \\
\hline 20 & Pointe Théogène & 60.7743 & 14.5758 & 0.59 & 0.53 & 0.54 \\
\hline 21 & Malevaut & 60.7438 & 14.5454 & 0.41 & 0.4 & 0.56 \\
\hline 22 & Grande Anse Macabou & 60.7438 & 14.5151 & 0.41 & 0.66 & 0.72 \\
\hline 23 & Pointe Macré & 60.8047 & 14.4848 & 0.66 & 0.8 & 0.83 \\
\hline 24 & Cap Ferré & 60.8047 & 14.4545 & 0.52 & 0.5 & 0.56 \\
\hline 25 & Cap Chevalier & 60.8047 & 14.4242 & 0.44 & 0.34 & 0.32 \\
\hline 26 & Pointe d'Enfer & 60.8656 & 14.3939 & 0.36 & 0.34 & 0.5 \\
\hline 27 & Sainte-Anne & 60.9256 & 14.4242 & 1.14 & 1.02 & 0.93 \\
\hline 28 & Grande-Pointe & 60.9874 & 14.4242 & 0.51 & 0.47 & 0.48 \\
\hline 29 & Le Diamant & 61.0179 & 14.4545 & 0.65 & 0.54 & 0.43 \\
\hline 30 & Roche du Diamant & 61.0179 & 14.4242 & 0.39 & 0.34 & 0.34 \\
\hline 31 & Pointe du Diamant & 61.0483 & 14.4242 & 0.36 & 0.4 & 0.46 \\
\hline 32 & Les Trois-Iles & 61.0483 & 14.5454 & 0.39 & 0.31 & 0.42 \\
\hline
\end{tabular}

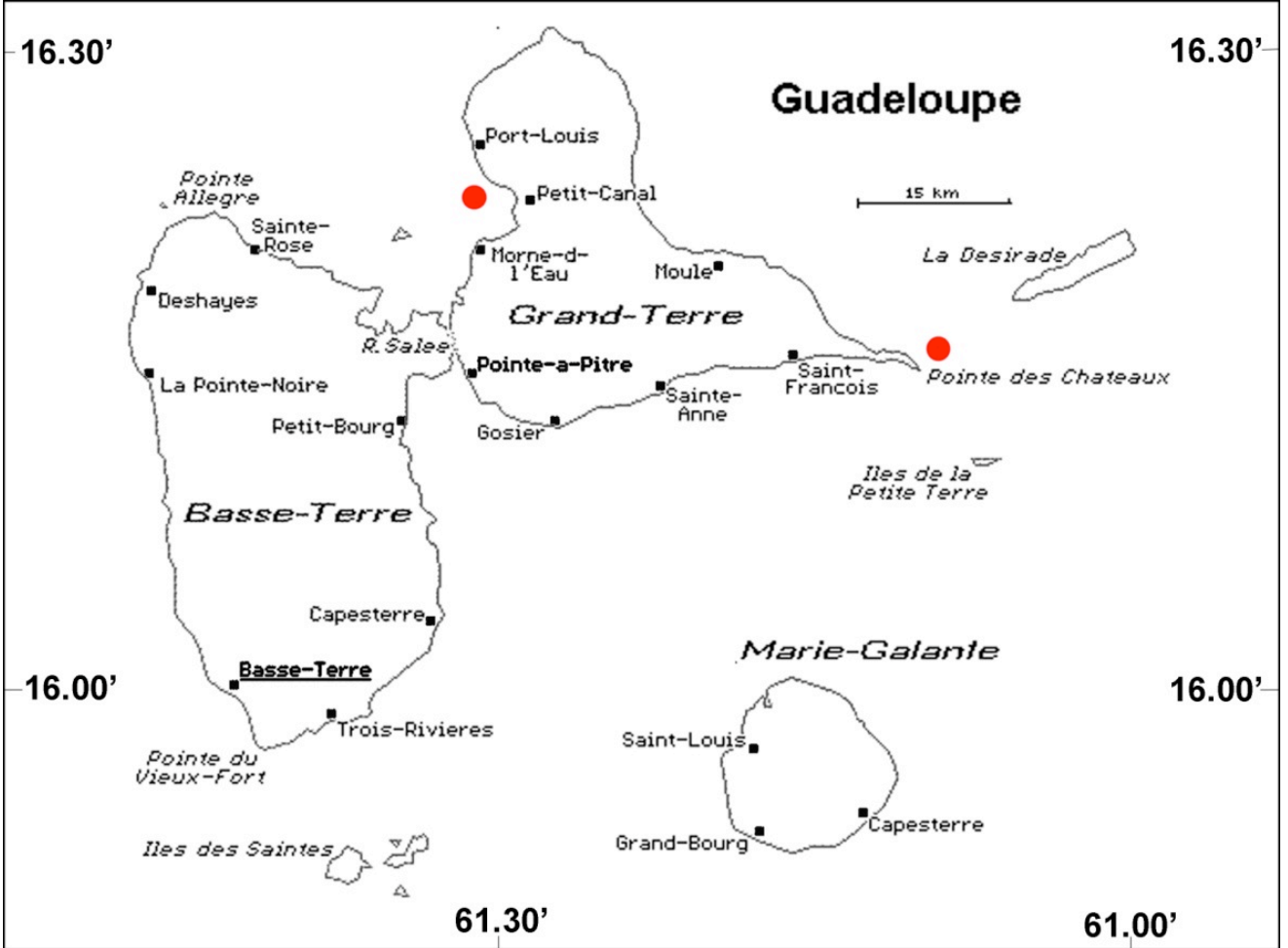

Fig. (10). The settlement in Guadeloupe Island (red points indicate the locations where the positive tsunami amplitude exceeds $1 \mathrm{~m}$ in simulations of 1755 . 


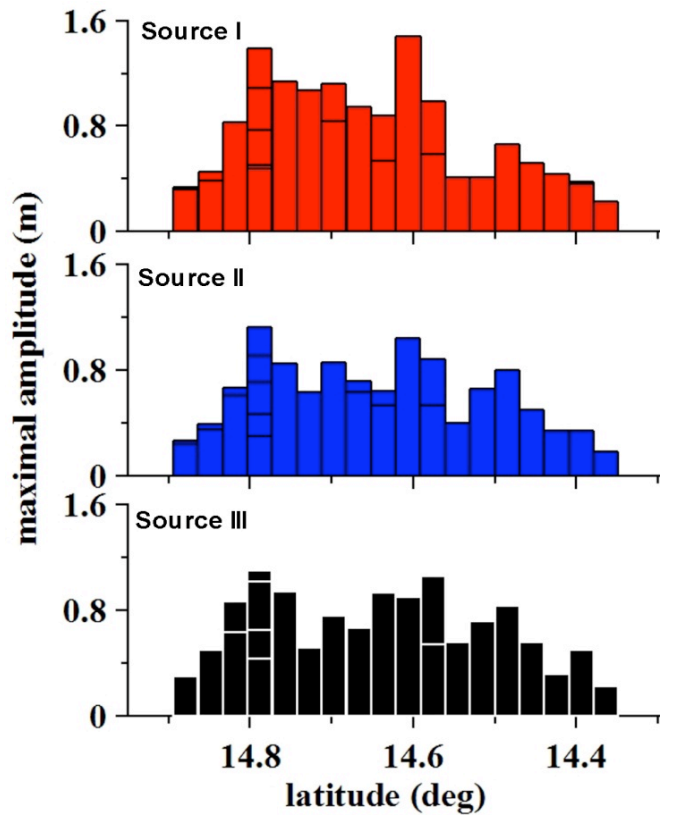

Fig. (11). Distribution of positive wave amplitude along the eastern coast of Martinique.

$\left(60.9570^{\circ} \mathrm{W} 14.7879^{\circ} \mathrm{N}\right)$ and Pointe Banane $\left(60.8352^{\circ} \mathrm{W}\right.$ $\left.14.7273^{\circ} \mathrm{N}\right)$, the computed tsunami amplitudes exceed $1 \mathrm{~m}$. These 6 locations are indicated in Fig. (12). In case of a tsunami generated near Gorrige bank and the Gibraltar subduction, higher tsunami amplitudes may be expected in these locations near Martinique.

In average the positive tsunami amplitudes near the eastern Martinique coast (Fig. 11) are higher at the center of eastern coast of Martinique when compared with the distribution at Guadeloupe (Fig. 9). There are two maxima at $14.8^{\circ} \mathrm{N}$ and $14.6^{\circ} \mathrm{N}$, in Martinique, but the maximal values are lower than the ones in Guadeloupe. Based on this, it may be said that the number of points where tsunami wave amplitude is about $1 \mathrm{~m}$ near the Martinique coast is higher than the ones near the Guadeloupe coast, but the highest wave amplitudes may be expected to occur near Guadeloupe.

Considering the amplification factor, the computed tsunami amplitudes along the eastern coast of Martinique (1$1.5 \mathrm{~m}$ ) can lead to the runup heights up to $2-4 \mathrm{~m}$. Our simulation results are in good agreement with observed tsunami runup $(1.8 \mathrm{~m})$ in Martinique [12].

\section{CONCLUSIONS}

The 1755 transatlantic tsunami caused by the Lisbon earthquake is modeled by using three similar seismic sources of different strike angles. The rupture parameters suggested by Gutscher et al., [14] are used as input. In the numerical simulations, the nonlinear form of shallow water equations considering the Earth sphericity and Coriolis effect are used. According to the simulation results, tsunami energy is

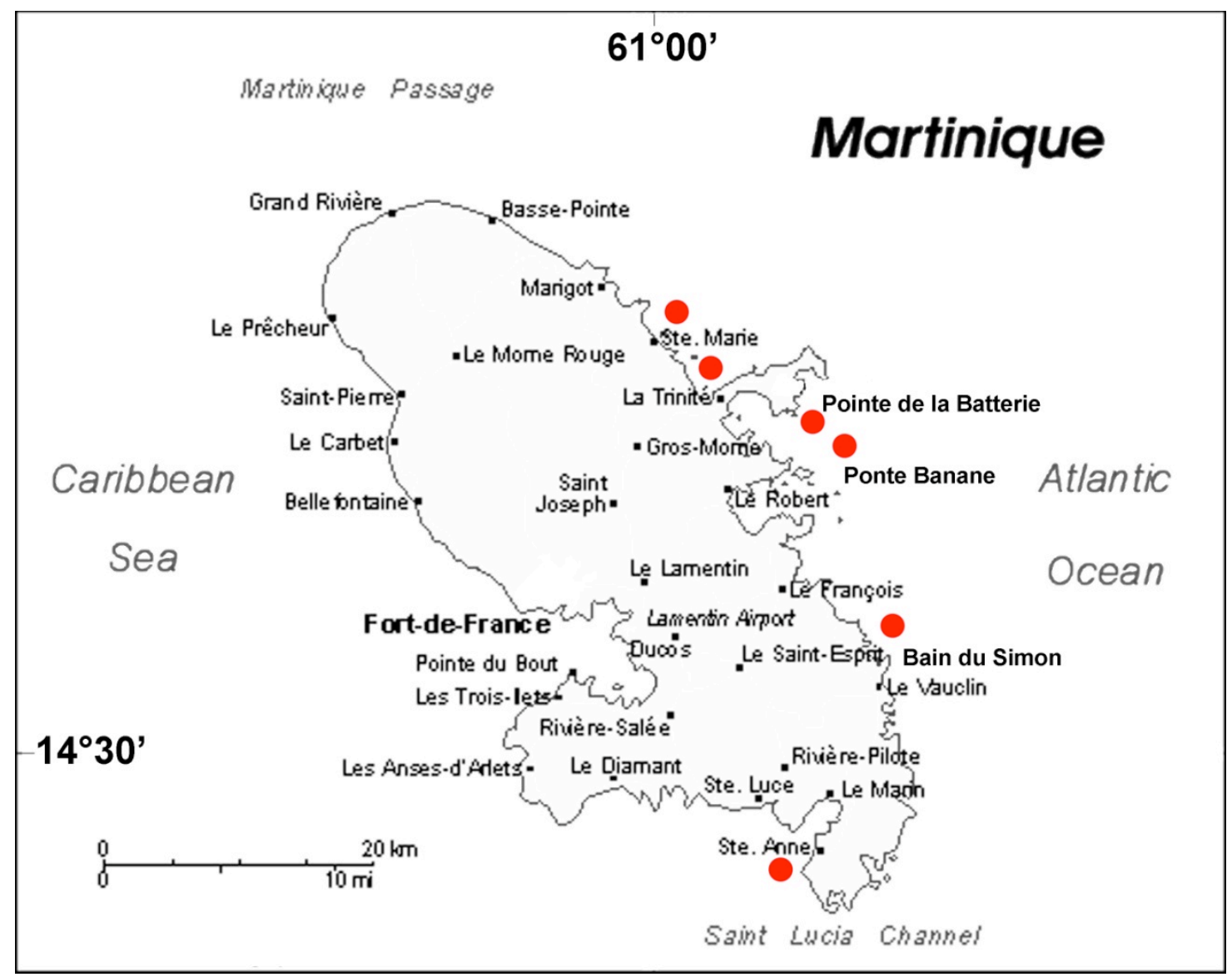

Fig. (12). The settlement in Martinique Island (red points indicate the locations where the positive tsunami amplitude exceeds $1 \mathrm{~m}$ in simulations of 1755). 
divided into two parts; one propagates mainly towards the western direction (Florida and the Bahamas) and the other towards southern direction (Brazil). Furthermore, the effect of this tsunami is found to be less in the Lesser Antilles compared to South and North America. The same has been demonstrated in [25] for another three earthquake sources. This peculiarity of tsunami propagation is more dependent on the bathymetry in the Atlantic Ocean rather than rupture orientation and dimension. It should also be noted that the nearshore topography might cause unexpected amplifications in some locations.

However, the amplitudes of tsunami waves computed in the open sea near Guadeloupe and Martinique reach a few ten centimeters. The travel time of the tsunami propagation from the epicenter (Lisbon, Portugal) to the Lesser Antilles is found to be about 7 hours. This result is also in agreement with the results of other researchers [20, 24, 33].

The analyses of computed time histories of tsunami wave near Guadeloupe reveal that the wave is leading depression type with very small trough (less than $8 \mathrm{~cm}$ ). The positive amplitudes of the first wave are found to be in the range between $26 \mathrm{~cm}$ (source I) and $44 \mathrm{~cm}$ (source III). The negative amplitudes of the first wave are found to be in the range between $-33 \mathrm{~cm}$ (source II) and $-40 \mathrm{~cm}$ (sources I, III). The second peak is computed as $0.38 \mathrm{~cm}$ (source I) and 57 $\mathrm{cm}$ (source III) high. The lowest level of water surface reaches $-66 \mathrm{~cm}$ (source I). Characteristic periods of the first and second waves (according to zero up crossing method) are obtained as 40 and 45 minutes respectively for all source alternatives.

The computed distributions of tsunami amplitudes near the coast of Guadeloupe show that the highest amplitude was near Pointe des Chateaux, east of Guadeloupe $\left(-61.1397^{\circ} \mathrm{W}\right.$ $16.2121^{\circ} \mathrm{N}$ ), which is equal to $2.17 \mathrm{~m}$ (source I), $1.94 \mathrm{~m}$ (source II) and $1.78 \mathrm{~m}$ (source III). The deviations of maximal wave heights around Guadeloupe are about $15-20 \%$ and few times more than $30 \%$ for three various source orientations. In fact, no historical records of 1755 tsunami are available in Guadeloupe, but our estimations are with agreement with observed heights of tsunami waves in Antigua and Dominica (3.6 m), in Guadeloupe (2-3 m).

The same analyses are performed for the distribution of tsunami wave amplitudes along the eastern coast of Martinique. The deviations of maximal wave heights around Martinique are about $20-30 \%$ in average for three various source orientations. The simulations results indicate that totally six virtual tide-gauge records (out of 32) had the positive wave amplitudes exceeding $1 \mathrm{~m}$. The maximum amplitude $(1.5 \mathrm{~m}$, source $\mathrm{I})$ is computed in Bain du Simon $\left(-60.8352^{\circ} \mathrm{W}, 14.6061^{\circ} \mathrm{N}\right)$ on Martinique. Considering the amplification factor (2-3), computed tsunami amplitudes (1-1.5 m) can lead to the runup heights up to 2-4 m. Computed results are found in accordance with the observed tsunami heights $(1.8 \mathrm{~m})$ on Martinique.

The simulation efforts and the analysis of the results given in this study confirm that the distant tsunamis originating from an area near Gorringe Bank are potentially dangerous for the Lesser Antilles, as well as the northern Atlantic coast of South America and the southern North America.

\section{ACKNOWLEDGEMENTS}

This research is supported particularly by the Programme Interreg IIIB Espaces Caribes, Programme de prevention des catastrophes naturelles (for NZ, EP, TT and IN), grants from RFBR (11-05-00216) for EP. Yalçiner thanks TUBITAK for the previous grants DEBAG-38, INTAS 847, YDABCAG 60 . The authors acknowledge partial support of UNESCOIOC and INTAS Ref. Nr 05-109-5100 for development of the code. This study is also partly supported by European Union Projects TRANSFER (Tsunami Risk and Strategies for the European Region) funded by the CEC, contract no. 037058, FP6-2005-Global-4, and Russia-Turkey Joint Research Grant by RFBR and TUBITAK 108 Y 227.

\section{REFERENCES}

[1] Lander JF, Whiteside LS, Lockridge PA. A brief history of tsunami in the Caribbean Sea. Sci Tsunami Hazard 2002; 20: 57-94.

[2] HTDB/ATL Expert Tsunami Database for the Atlantics. Version 3.6 of March 15, 2002. Tsunami Laboratory, Novosibirsk, Russia, 2002.

[3] O'Loughlin KF, Lander JF. Caribbean Tsunamis: A 500-Year History from 1498-1998, Adv Nat Technol Haz Springer 2003; pp. 280.

[4] Zahibo N, Pelinovsky E. Evaluation of tsunami risk in the lesser antilles. Nat Hazard Earth Sys Sci 2001; 1(4): 221-31

[5] Zahibo N, Pelinovsky E, Yalçiner A, Kurkin A, Koselkov A, Zaitsev A. The 1867 Virgin Island Tsunami: observations and modeling. Oceanol Acta 2003; 26(5-6): 609-21.

[6] Zahibo N, Pelinovsky E, Kurkin A, Kozelkov A. Estimation of farfield tsunami potential for the Caribbean Coast based on numerical simulation. Sci Tsunami Hazard 2003; 21(4): 202-22.

[7] Zahibo N, Pelinovsky E. In: Mercado-Irizarry A, Liu P, Eds Tsunamis in the Lesser Antilles. Caribbean Tsunami Hazard. World Sci Singapore, 2006; pp. 244-54.

[8] Baptista MA, Miranda PMA, Miranda JM, Mendes Victor L. Constrains on the source of the 1755 Lisbon tsunami inferred from numerical modelling of historical data on the source of the 1755 Lisbon tsunami. J Geodyn 1998; 25: 159-74.

[9] Baptista MA, Miranda JM, Chierici F, Zitellini N. New study of the 1755 earthquake source based on multi-channel seismic survey data and tsunami modeling. Nat Hazard Earth Sys Sci 2003; 3: 333-40.

[10] Nikolkina I, Zahibo N, Pelinovsky E. Tsunami in guadeloupe (Caribbean Sea). Open Oceanogr J 2010; 4: 44-9.

[11] NGDC (National Geophysical Data Center) Tsunami Database, Available at http://www.ngdc.noaa.gov/seg/hazard/tsu_db.shtml, 2006.

[12] Morton RA, Richmond BM, Jaffe BE, Gelfenbaum G. Reconnaissance investigation of Caribbean extreme wave deposits - preliminary observations, interpretations, and research directions, USGS, Open-File Report 2006-1293, 2006; p. 46.

[13] Johnston A. Seismic moment assessment of earthquakes in stable continental regions - III. New Madrid, 1811-1812, Charleston 1886 and Lisbon 1755. Geophys J Int 1996; 126: 314-44.

[14] Gutscher M-A, Baptista MA, Miranda JM. The Gibraltar Arc seismogenic zone (part 2): constraints on a shallow east dipping fault plane source for the 1755 Lisbon earthquake provided by tsunami modeling and seismic intensity. Tectonophysics 2006; 426 (1-2): 153-66.

[15] Zitellini N, Mendes Victor LA, Cordoba JD, et al. Source of 1755 Lisbon earthquake and tsunami investigated. EOS 2001; 82: 26.

[16] Gracia E, Danobeitia JJ, Verges J, PARSIFAL Team. Mapping active faults offshore Portugal $\left(36^{\circ} \mathrm{N}-38^{\circ} \mathrm{N}\right)$ : implications for seismic hazard assessment along the southwest Iberian margin. Geology 2003; 31: 83-6.

[17] Guiesmia M, Heinrich P, Mariotti C. Numerical simulation of the 1969 Portuguese tsunami by a finite element method. Nat Hazards 1998; 17: 31-46.

[18] Fukao Y. Thrust faulting at a lithospheric plate boundary: the Portugal earthquake of 1969. Earth Planet Sci Lett 1973; 18: 20516. 
[19] Levret A. The effects of the November 1, 1755 "Lisbon"'earthquake in Morocco. Tectonophysics 1991; 193: 8394.

[20] Gjevik B, Pedersen G, Dybesland E, et al. Modeling tsunamis from earthquake sources near Gorringe Bank southwest of Portugal. J Geophys Res 1997; 102 (C13): 27931-49.

[21] Okada Y. Surface deformation due to shear and tensile faults in a half-space. B Seismol Soc Am 1985; 75: 1135-54.

[22] Stich D, de Lis Mancilla F, Pondrelli S, Morales J. Source analysis of the February 12th 2007, Mw 6.0 Horseshoe earthquake: Implications for the 1755 Lisbon earthquake. Geophys Res Lett 2007; 34: L12308, doi:10.1029/2007GL030012.

[23] Horsburgh KJ, Wilson C, Baptie BJ, et al. Impact of a Lisbon-type tsunami on the U.K. coastline and the implications for tsunami propagation over broad continental shelves. J Geophys Res 2008; 113: C04007, doi:10.1029/2007JC004425.

[24] Mader CL. Modeling the 1755 Lisbon tsunami. Sci Tsunami Hazard 2001; 9: 93-8.

[25] Roger J, Allgeyer S, Hébert H, Baptista MA, Loevenbruck A, Schindel F. The 1755 Lisbon tsunami in guadeloupe archipelago: contribution of numerical modelling. Open Oceanogr J 2010; 4: 5870.

[26] Barkan R, ten Brink U, Lin J. Far field tsunami simulations of the 1755 Lisbon earthquake: implications for tsunami hazard to the U.S. East Coast and the Caribbean. Mar Geol 2009; 109-122, doi:10.1016/j.margeo.2008.10.010.
[27] Kurkin AA, Zaitsev AI, Yalçiner A, Pelinovsky EN. Modified computing package "TSUNAMI" for risk estimations due to tsunami wave. Izv Russ A Eng Appl Math Mech 2004; 9: 88-100.

[28] Goto C, Ogawa Y, Shuto N, Imamura N. Numerical method of tsunami simulation with the leap-frog scheme (IUG/IOC Time Project) IOC Manual. UNESCO Paris 1997; 35.

[29] Zaitsev AI, Kurkin AA, Levin BV, et al. Numerical simulation of catastrophic tsunami propagation in the Indian Ocean. Dokl Earth Sci 2005; 402(4): 614-8.

[30] Yalçiner AC, Pelinovsky E, Zaytsev A, et al. In: Kundu A, Ed. Modeling and visualization of tsunamis: Mediterranean examples. Tsunami and Nonlinear Waves. Heidelberg, Berlin: Springer 2007; pp. 273-83.

[31] Yalçiner A, Alpar B, Altinok Y, Ozbay I, Imamura F. Tsunamis in the Sea of Marmara. Historical documents for the past, models for the future. Mar Geol 2002; 190: 445-63.

[32] Yalçiner A, Pelinovsky E, Talipova T, Kurkin A, Kozelkov A, Zaitsev A. Tsunamis in the Black Sea: comparison of the historical, instrumental and numerical data. J Geophys Res 2004, 109: C12, C12023 10.1029/2003JC002113.

[33] Løvholt F. Numerical modeling of tsunami generation and propagation. PhD Thesis. University of Oslo 2008.

[34] Synolakis CE. The runup of solitary waves. J Fluid Mech 1987; 185: 523-45.

[35] Pelinovsky EN. Tsunami wave hydrodynamics, Nizhny Novgorod, Institute Applied Physics Press, 1996; pp. 276.

(C) Zahibo et al.; Licensee Bentham Open.

This is an open access article licensed under the terms of the Creative Commons Attribution Non-Commercial License (http://creativecommons.org/licenses/by$\mathrm{nc} / 3.0 /$ ), which permits unrestricted, non-commercial use, distribution and reproduction in any medium, provided the work is properly cited. 